\title{
Myopathic changes in a muscular dystrophy carrier
}

\author{
VICTOR DUBOWITZ
}

\author{
From the Department of Child Health, University of Sheffield
}

This investigation of a 34-year-old female carrier of muscular dystrophy was prompted by the observation that the circumference of her left calf was $1 \mathrm{in}$. larger than that of the right (Fig. 1). She thought that this difference had been present since the age of 13 and from that time she had experienced cramps in the left calf when playing games and when walking or running downhill. The muscle would then 'pull tight' and the pain would subside again with rest. She had never noticed any muscular weakness.

On the basis of the family history and the results of serum enzyme studies this woman is thought to be a carrier.

\section{FAMILY HISTORY}

One of her brothers (II, 6) died of muscular dystrophy at the age of 19. Her 7-year-old son (IIl, 3) has the typical Duchenne type of muscular dystrophy. According to her eldest sister, the brother who died had the identical pattern of disease.

$$
\text { CASE HISTORY (III, 3) }
$$

His symptoms were first noted at the age of 2 when he began to walk. He had a waddling gait and his calves were prominent. He gradually became weaker, had great difficulty getting up stairs, and was unable to run. He fell frequently, his legs often giving way under him for no apparent reason, and he got up from the ground in a 'stiff-legged' fashion. He intermittently complained of cramps in the calves, especially when walking. The calf muscles were then noted to contract into a firm ball and the heels were raised from the ground.

When first examined at the age of 7 he had the typical distribution of weakness of the Duchenne type dystrophy, affecting mainly the trunk, proximal limb, and anterior neck muscles. He had a waddling gait with associated $\mathrm{O}$ lumbar lordosis and got up from the floor by the Gowers' manoeuvre. The calves were still prominent. The ankle jerks were present, the other tendon jerks absent.

\section{SERUM ENZYMES}

The level of creatine phosphokinase in the propositus was 565 units and in the mother 20.3 units (normal less than 4 units) and of the serum aldolase 199 units $O$ in the propositus and 28.4 units in the mother (normal less than 25 units).

The very high level of aldolase and creatine phosphokinase in the propositus were consistent with a diagnosis of an early case of Duchenne type musculat $\dot{\omega}$ dystrophy. The raised levels in the mother suggested $\mathrm{N}$ carrier state (Schapira, Dreyfus, Schapira, and Demos 1960; Aebi, Richterich, Colombo, and Rossi, 196 Hughes, 1962).

\section{METHOD}

A muscle biopsy was obtained under local anaesthesi from the medial head of the left gastrocnemius of the mother. It was rapidly frozen in liquid nitrogen and sectioned in a cryostat at $-30^{\circ} \mathrm{C}$. (Dubowitz and Pearse, 1961). Sections were stained with haematoxylin and eosin, haemalum and Van Gieson and Best's carmine, and serial sections were examined histochemically for the following enzymes: diphosphopyridine nucleotide $\mathbb{Q}$ (D.P.N.), diaphorase, lactate dehydrogenase, phosphorylase, adenosine triphosphatase, and 5-nucleotidase.

\section{RESULTS}

The stained sections showed extensive myopathic changes (Figs. 2-6). The muscle fibres were still

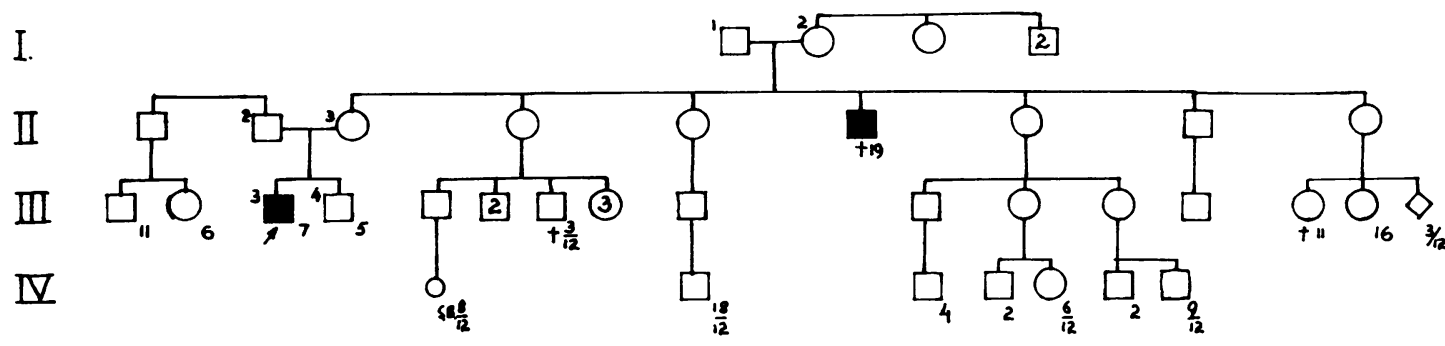




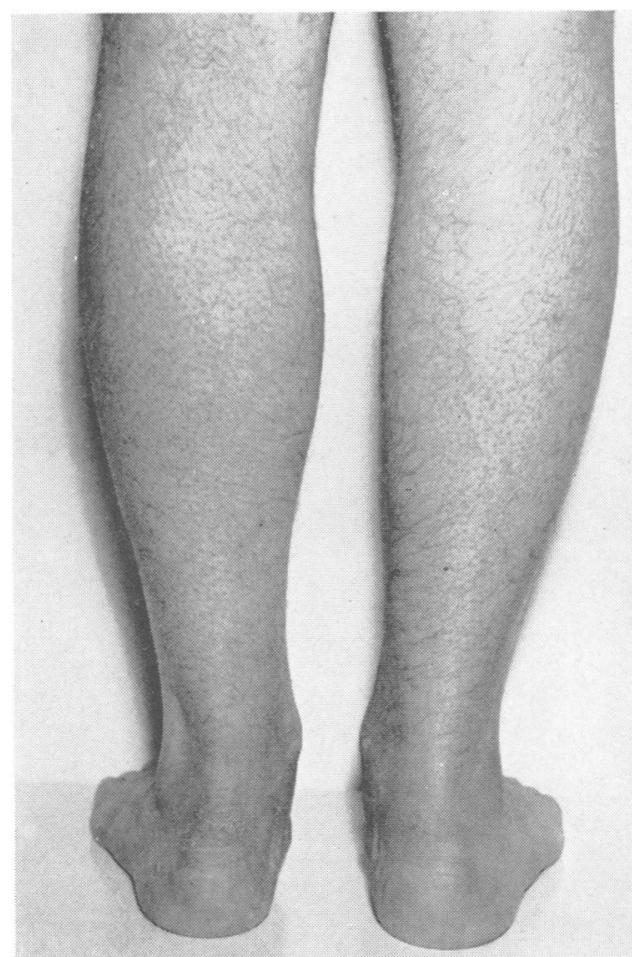

FIG. 1. Relative prominence of left calf.

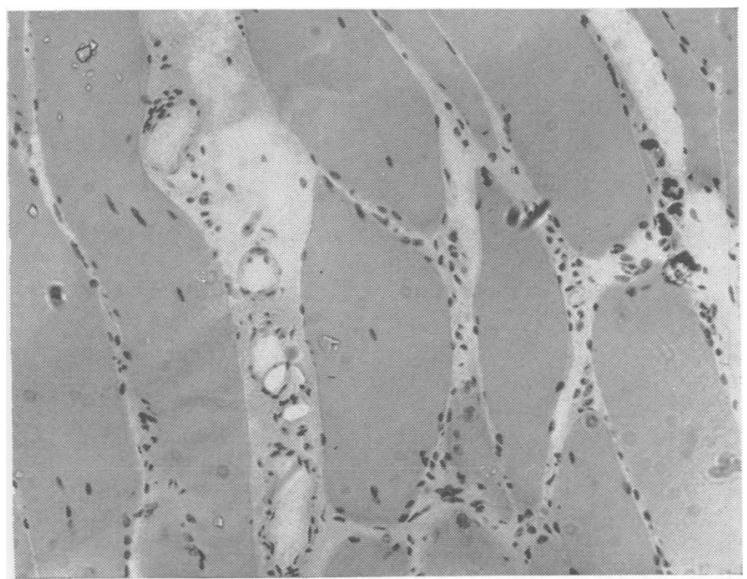

FIG. 2. Longitudinal section showing variation in fibre size, internal nuclei, proliferation and cellularity of endomysial connective tissue. Haematoxylin and eosin $\times 110$.

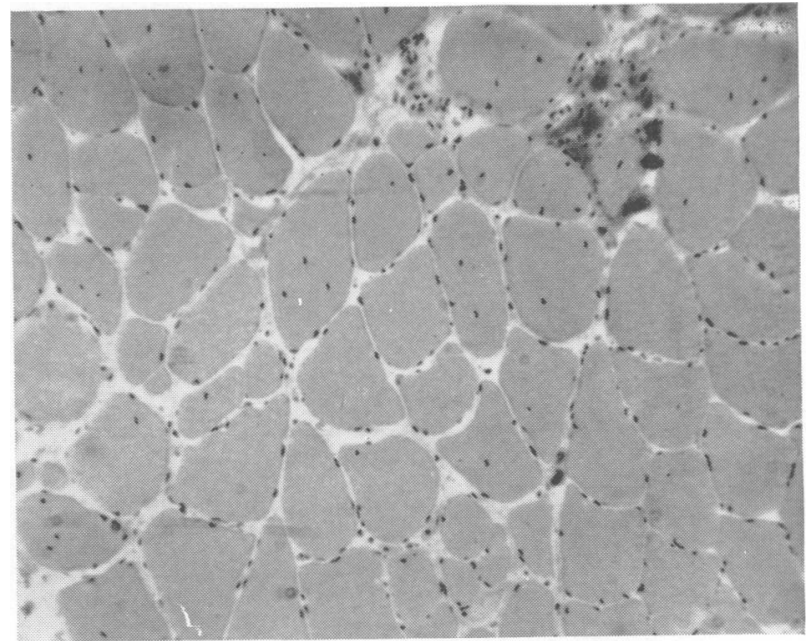

FIG. 3. Transverse section: note variation in fibre size, internal nuclei, splitting of muscle fibres, and condensation of connective tissue around degenerating fibres. Van Gieson $\times 90$.

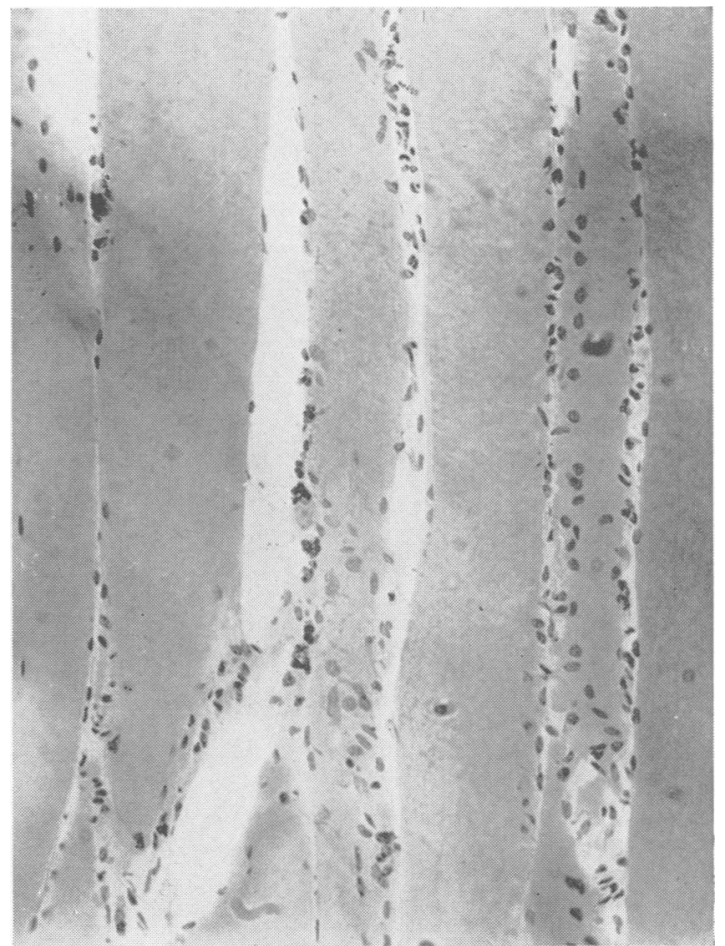

FIG. 4. Longitudinal section showing fibres undergoing phagocytosis. Van Gieson $\times 120$. 


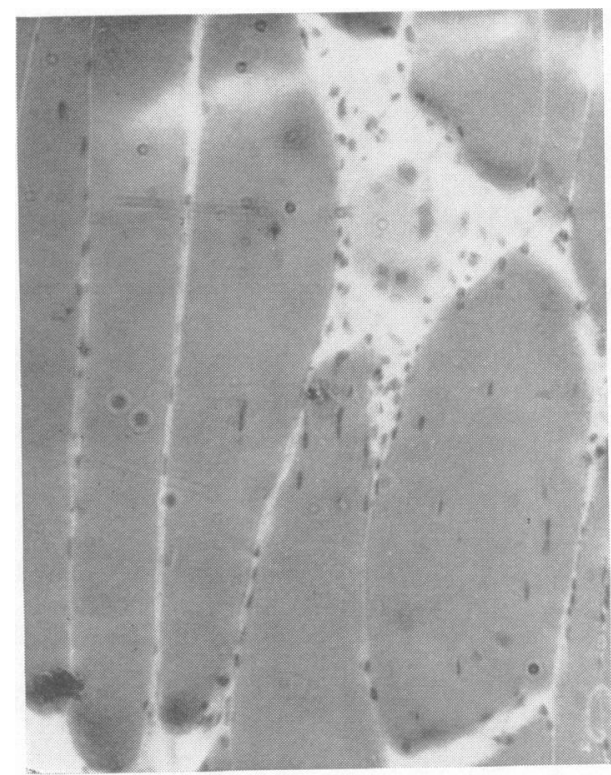

FIG. 5. Longitudinal section showing basophilic staining of 'regenerating' fibre and variation in fibre diameter. Haematoxylin and eosin $\times 130$.

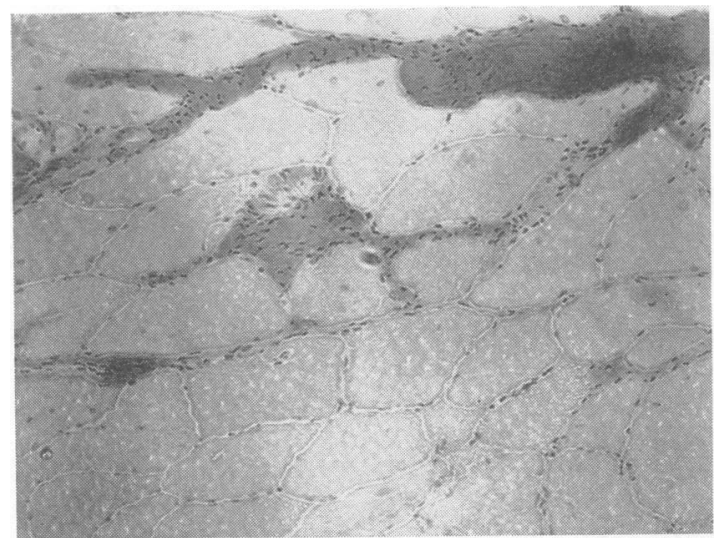

FIG. 6. Transverse section showing proliferation of perimysial and endomysial connective tissue. Van Gieson $\times 100$.

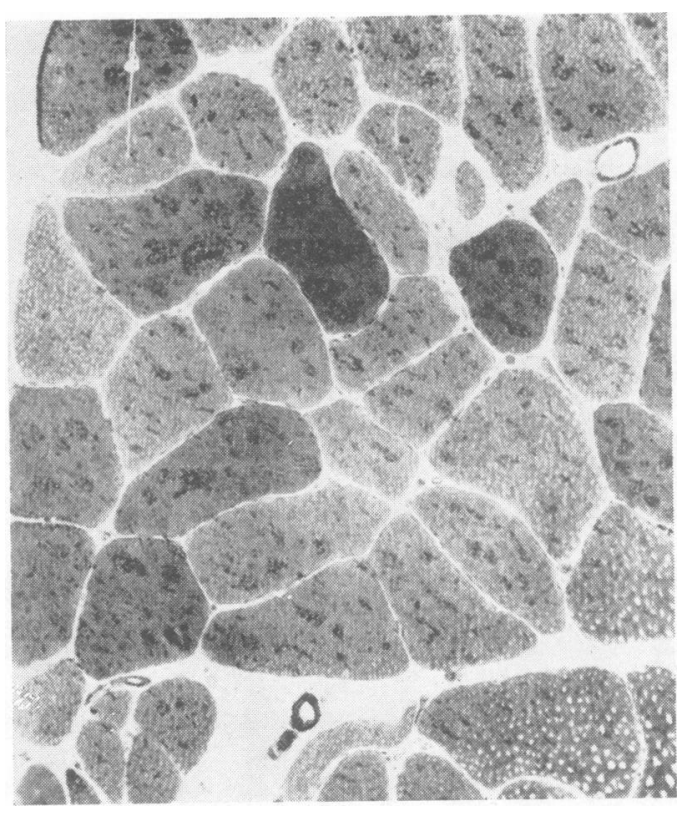

FIG 7 Transverse section. Adenosine triphosphatase 0 Note variation in enzyme content of fibres. $\times 110 . \frac{0}{\mathrm{~N}}$

응

适

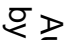

웅

量

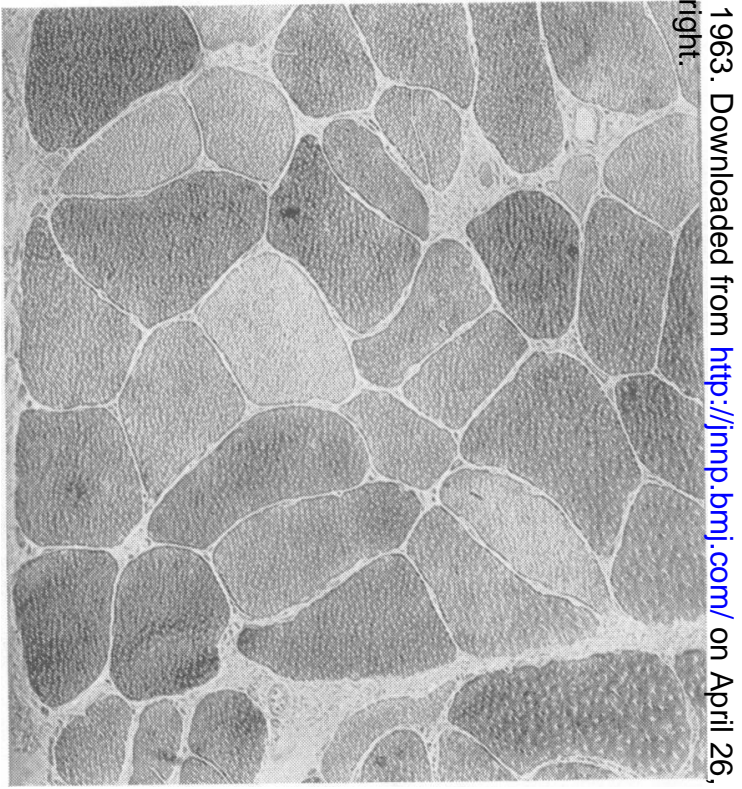

FIG. 8. Serial section. Phosphorylase. Same fibres as in Fig. 7 react strongly. 
arranged in bundles but varied considerably in size and shape. The majority were larger than normal and ranged from 60 to $140 \mu$ in diameter. There were also numerous atrophic fibres, many of which were under $20 \mu$ in diameter. Occasional fibres showed hyaline degeneration and appeared to be undergoing phagocytosis. Others were basophilic in staining and contained large round nuclei. Some fibres showed longitudinal splitting.

The sarcolemmal nuclei averaged 8-10 per transverse section. Many fibres had one or more internal nuclei and in longitudinal section some of these were arranged in chains. Some of the nuclei were large and round with a central nucleolus; others looked more like swollen sarcolemmal nuclei or fibroblast nuclei. There was proliferation of perimysial and endomysial connective tissue, particularly in the region of atrophic fibres. The connective tissue was highly cellular.

The enzyme reactions appeared normal. The fibres showed a normal variation in enzyme content. Fibres rich in phosphorylase also gave a strong reaction for adenosine triphosphatase (Figs. 7 and 8) and these fibres were weak in lactate dehydrogenase and D.P.N. diaphorase. 5-Nucleotidase was present in the connective tissue of the perimysium and the walls of the blood vessels. A positive reaction also occurred in the connective tissue around some of the degenerative fibres. Best's carmine stain for glycogen was visible in all fibres. There was a slight variation in intensity between fibres but this was not sufficiently striking to correlate with the enzyme reactions.

\section{DISCUSSION}

The pathological changes in this woman's muscle are assumed to be associated with her carrier state because of their close resemblance to the changes in typical muscular dystrophy. Erb (1891) listed the main changes in dystrophic muscle as variable hyperplasia of the interstitial connective tissue and adipose tissue, hypertrophy or atrophy of muscle fibres, marked proliferation of nuclei in the fibres, and division of fibres in their longitudinal axis. Similar descriptions have been given by recent authors (Adams, Denny-Brown, and Pearson, 1953;
Greenfield. Shy, Alvord, and Berg, 1957; Pearson, 1962).

Prominence of the calf muscle in a carrier is unusual; so is a history of pain in the calves. However, these are not symptoms about which routine questions are asked of mothers of dystrophic children. They would have been missed in this case, but for a chance observation. On the other hand, in children with progressive muscular dystrophy cramp in the leg muscles is a common symptom. I obtained a positive history of it in 24 out of 65 cases (Dubowitz, 1960).

The finding of dystrophic changes in the muscle of this carrier supports the view that the raised serum levels of creatine phosphokinase or aldolase in carriers reflects the abnormal leakage of cytoplasmic enzymes from the muscle cell (Aebi et al., 1961) rather than a primary metabolic defect.

A pathological study of the muscle from further known carriers will be necessary to confirm these observations and to try and correlate histological changes in the muscle with the presence or absence of a raised level of serum enzymes.

This work is being supported by grants from the Muscular Dystrophy Group and the Sheffield University Research Fund.

I am grateful to Dr. Cedric C. Harvey for referring the patient and to the mother for her courage and cooperation. I wish to thank Miss Joan Wingfield for her able and enthusiastic technical assistance, Dr. B. P. Hughes for the serum enzyme estimations, and Mr. R. Cousins and Mr. A. K. Tunstill for the photographs.

\section{REFERENCES}

Adams, R. D., Denny-Brown, D., and Pearson, C. M. (1953). Diseases of Muscle. A Study in Pathology, 1st ed. Hoeber, New York.

Aebi, U., Richterich, R., Colombo, J. P., and Rossi, E. (1961). Enzymol. biol. clin., 1, 61.

Dubowitz, V. (1960). Progressive Muscular Dystrophy in Childhood. M.D. Thesis. University of Cape Town.

- and Pearse, A. G. E. (1961). J. Path. Bact., 81, 365.

Erb, W. (1891). Dtsch. Z. Nervenheilk., 1, 13.

Greenfield, J. G., Shy, G. M., Alvord, E. C., and Berg, L. (1957). An Atlas of Muscle Pathology in Neuromuscular Diseases. Livingstone, Edinburgh and London

Hughes, B. P. (1962). Brit. med. J., 2, 963.

Pearson, C. M. (1962). Brain, 85, 109.

Schapira, F., Dreyfus, J. C., Schapira, G., and Demos, J. (1960). Rev. franç. Etud. clin. biol., 5, 990. 